\title{
Nostoc sp. extract induces oxidative stress- mediated root cell destruction in Mimosa pigra L.
}

\author{
Siriphan Sukkhaeng, Nuttha Sanevas and Srisom Suwanwong*
}

\begin{abstract}
Background: Mimosa pigra is an invasive weed in some regions of South East Asia and Australia. Our previous study has revealed that a cyanobacterium, Nostoc sp., extract can inhibit root growth in M. pigra seedlings. In this study, some physiological processes involve oxidative stress-mediated cell death and root ultrastructure were investigated to clarify the mechanisms of root growth suppression and bioherbicidal potential of the extract.

Results: Nostoc sp. extract enhanced overproduction of reactive oxygen species (ROS) at $24 \mathrm{~h}$, the intensity of red fluorescence increased at $72 \mathrm{~h}$, and caused a slightly increased $\mathrm{H}_{2} \mathrm{O}_{2}$ consistent with the activation of scavenging enzymes (catalase, ascorbic acid peroxidase, glutathione reductase, and peroxidases). This suggests that oxidative stress occurred in the presence of the extract which was supported by increased cell death and lipid peroxidation at $24 \mathrm{~h}$. Reduction of malondialdehyde content and an increase in cell death at $72 \mathrm{~h}$ indicated oxidative damage and cellular leakage. Ultrastructural changes were determined at $72 \mathrm{~h}$ by scanning electron micrographs which confirmed the damage of epidermal and root cap cells and the disaggregation and destruction of root tip cells. Transmission electron micrographs showed the dissolution of the middle lamella, deposition of some substances in vacuoles, and abnormal mitochondria (swollen mitochondria and indistinct cristae).
\end{abstract}

Conclusions: Nostoc sp. extract enhance oxidative stress by ROS production resulting in lipid peroxidation and massive cell death despite the activation of antioxidative enzymes. Understanding mechanism of action of Nostoc sp. extract will provide information for application of the extract to use as natural herbicide for control of M. pigra.

Keywords: Nostoc sp; Oxidative stress; Lipid peroxidation; Cell death; Root ultrastructure; Mimosa pigra

\section{Background}

Cyanobacteria are known to produce various kinds of secondary metabolites that can affect many biochemical processes within cells and can influence the growth of surrounding organisms (Leflaive and Ten-Hage 2007). Natural products from cyanobacteria exhibit various biological inhibitory effects which are cytotoxic, antibacterial, antifungal, and antialgal (Etchegaray et al. 2004; Kreitlow et al. 1999; Kulik 1995). Cyanobacteria have been recognized as options for novel bioactive natural products and use as bio-control agents and herbicides due to their inhibitory activities against some aquatic and terrestrial plants, especially weeds (Duke et al. 2002; Berry et al. 2008).

Nostoc sp., a filamentous cyanobacterium (Nostocales), has been reported to produce some chemical substances

\footnotetext{
*Correspondence: fscisss@ku.ac.th

Department of Botany, Faculty of Science, Kasetsart University, Bangkok 10900, Thailand
}

affecting on various organisms. For example, an alkaloid nostocarboline had an inhibitory activity on Microcystis aeruginosa (Blom et al. 2006). Nostocyclamide, a cyclic peptide, had antialgal activity and growth inhibitory activities against cyanobacteria and Chlorophyceae (Kobayashi and Kajiyama 1998). The effect on higher plants was reported by Hirata et al. (2003) that nostocine A produced by Nostoc spongiaeforme TISTR 8169 exhibited an inhibitory activity on root growth of barnyard grass (Echinochloa crus-galli (L.) P. Beauv.). It is possible that Nostoc species has weed suppressing potential. Not much is known about the mechanism of Nostoc extract.

Understanding the mechanism of natural plant compounds is important for research in natural herbicides. Under unfavorable conditions, such as high or low temperature, water deficit, salinity, and some chemical substances, normal metabolisms of plants are disturbed and toxic molecules are produced (Mano 2002). One of these toxic molecules is ROS which can abstract

\section{穴}


hydrogen atoms from polyunsaturated fatty acids (the composition of biological membranes), initiate lipid peroxidation, and cause cell death. During this processes, plants suffer from oxidative stress and malondialdehyde (MDA) is produced as a by-product (Halliwell and Chirico 1993; Gutteridge 1995). Because of ROS toxicity, plant cells have mechanisms to reduce these toxic compounds by ROS scavenging via antioxidative enzyme systems (Mittler 2002). Root ultrastructural changes have been used to study the damage of structures and organelles in root tips exposed to some allelochemicals. These include the decreases in the number of ribosome, dictyosome, mitochondria, endoplasmic reticulum, and metabolic products, mitochondrial swelling and loss of cristae, dissolution of the middle lamella, and the irregularshaped cells (Burgos et al. 2004; Jiang and Liu 2010; Yang et al. 2011).

In our previous study, crude extract from Nostoc sp. was effective on shoot and root growth suppression of $M$. pigra and had an adverse effect on mitotic cell division (Sukkhaeng et al. 2014), but the inhibition of cell division might not be the only major mechanism of root growth suppression. The aims of this study were to explore the effect of Nostoc sp. extract on ROS-mediated oxidative stress (superoxide anion radical $\left(\mathrm{O}_{2} \bullet^{-}\right)$and lipid peroxidation), ROS metabolism in terms of the alterations of antioxidative enzymes, and oxidative damage (cell death and root ultrastructural changes).

\section{Methods}

\section{Cyanobacteria culture and extraction}

A cyanobacterium, Nostoc sp. (BotKU C3004, voucher specimen is deposited at herbarium of the Department of Botany, Faculty of Science, Kasetsart University) was collected from rice straw in Bangkok, Thailand and isolated by the streak plate method. Nostoc cells were cultured in BG-11 liquid medium (Rippka et al. 1979), $\mathrm{pH} 6.5$ under daylight fluorescent lamps $(300 \mu \mathrm{mol}$ $\left.\mathrm{m}^{-2} \mathrm{~s}^{-1}\right)$ at ambient temperature $\left(32 \pm 3^{\circ} \mathrm{C}\right)$. The cells in the exponential phase of growth (15 days after culture) were harvested by means of filtration and subsequently dried at $50^{\circ} \mathrm{C}$ for $72 \mathrm{~h}$. The dried cells were ground to powder and extracted with $80 \%$ methanol for $24 \mathrm{~h}$ at ambient temperature. The solution was filtered and the supernatant was evaporated in a rotary evaporator to obtain a crude brown gum. The residue was extracted twice and the supernatant was combined with the first one.

\section{Bioassay}

The gummy substance was dissolved in water containing $0.1 \%$ dimethyl sulfoxide (DMSO) at $0,0.1,0.3$ and $0.5 \%$. Test solutions of various concentrations $(1.5 \mathrm{ml})$ were added to petri dishes $(5 \mathrm{~cm}$ in diameter) containing filter paper. Six seeds of $M$. pigra were placed on the filter paper and kept in the dark at ambient temperature for 24 and $72 \mathrm{~h}$. The water containing 0.1\% DMSO was used as a control.

\section{Determination of antioxidative enzyme activities}

Three hundred milligrams of frozen roots were crushed to a fine powder in a mortar under liquid nitrogen and homogenize with $3 \mathrm{ml}$ of $25 \mathrm{mM}$ potassium phosphate buffer ( $\mathrm{pH}$ 7.8) containing $0.4 \mathrm{mM}$ EDTA-4H, $1 \mathrm{mM}$ ascorbic acid, and 2\% PVPP. The homogenate was centrifuged at 12,000 rpm for $20 \mathrm{~min}$ at $4^{\circ} \mathrm{C}$ and the supernatant was used as an enzyme extract for the assays of catalase (CAT; EC 1.11.1.6), ascorbic acid peroxidase (APX; EC 1.11.1.11), glutathione reductase (GR; EC 1.6.4.2), and peroxidases (PODs; EC 1.11.1.7) activities.

CAT activity was assayed by determination of the initial rate of hydrogen peroxide disappearance according to Aebi (1983). Activity was measured spectrophotometrically at $240 \mathrm{~nm}\left(\mathrm{E}=0.0394 \mathrm{mM}^{-1} \mathrm{~cm}^{-1}\right)$. GR activity was determined by the method of Halliwell and Foyer (1978). Activity was determined at $340 \mathrm{~nm}$ by measuring the decrease of NADPH absorbance $\left(\mathrm{E}=6.1 \mathrm{mM}^{-1} \mathrm{~cm}^{-1}\right)$. APX activity was assayed by the method of Nakano and Asada (1987). Activity was determined at $290 \mathrm{~nm}$ by measuring the decrease of ascorbic acid $\left(E=2.8 \mathrm{mM}^{-1}\right.$ $\mathrm{cm}^{-1}$ ). PODs activity was determined by the method of Putter (1974). PODs activity was measured spectrophotometrically at $436 \mathrm{~nm}$ by the formation of guaiacol dehydrogenation products $\left(\mathrm{E}=25.5 \mu \mathrm{M}^{-1} \mathrm{~cm}^{-1}\right)$.

\section{Histochemical detection of ROS}

ROS production was estimated using a superoxide anion radical-specific oxidation-sensitive fluorescence dye, dihydroethidium (DHE) (Sunohara and Matsumoto 2008) with a minor modification. Treated roots were stained with $10 \mu \mathrm{M}$ DHE in $100 \mu \mathrm{M} \mathrm{CaCl}_{2}, \mathrm{pH} 4.75$, by gently shaking for $2 \mathrm{~h}$ at $25^{\circ} \mathrm{C}$ in the dark. The roots were then soaked in $100 \mu \mathrm{M} \mathrm{CaCl}_{2}$ for $5 \mathrm{~min}$ and observed using a fluorescence microscope (Nikon E600 with a B2A filter combination, excitation $450-490 \mathrm{~nm}$, emission $\geq 520 \mathrm{~nm}$ ).

\section{$\mathrm{H}_{2} \mathrm{O}_{2}$ determination}

Hydrogen peroxide content was determined according to Velikova et al. (2000). This method is based on potassium iodide (KI) oxidation by $\mathrm{H}_{2} \mathrm{O}_{2}$ to give iodide ion. Iodide reacts with iodine to form triiodide $\left(\mathrm{I}_{3}{ }^{-}\right)$which show absorption at $285 \mathrm{~nm}$ (Junglee et al. 2014). For every sample, distilled water was used instead of KI for tissue coloration background. $\mathrm{H}_{2} \mathrm{O}_{2}$ standard solutions were prepared for calibration curve. 


\section{Determination of root cell death}

Treated roots were stained with Evans blue solution $(0.025 \%(\mathrm{w} / \mathrm{v})$ in $100 \mu \mathrm{M} \mathrm{CaCl}, \mathrm{pH} 5.6)$ for $30 \mathrm{~min}$. Stained roots were washed 3 times with $100 \mu \mathrm{M} \mathrm{CaCl}_{2}$ ( $\mathrm{pH}$ 5.6), until the dye no longer eluted from the roots (Yamamoto et al. 2001). Ten root tips were excised (3 mm) and allowed to soak in $200 \mu \mathrm{l}$ of $N, N$-dimethylformamide for $24 \mathrm{~h}$. The absorbance of released Evans blue was measured at $600 \mathrm{~nm}$.

\section{Determination of lipid peroxidation}

The thiobarbituric acid test, which determines MDA as an end product of lipid peroxidation (Velikova et al. 2000), was used. The amount of thiobarbituric acidreactive substances, red pigments, was calculated from the extinction coefficient $155 \mathrm{mM}^{-1} \mathrm{~cm}^{-1}$.

\section{Root ultrastructural studies}

For scanning electron microscopy, excised root tips of $5 \mathrm{~mm}$ ( 0 and $0.5 \%$ at $72 \mathrm{~h}$ treated roots) were prefixed in $2.5 \%$ glutaraldehyde in a $0.1 \mathrm{M}$ sodium phosphate buffer ( $\mathrm{pH} 7.2$ ), postfixed in $2 \%$ osmium tetroxide for $2 \mathrm{~h}$., dehydrated in an acetone series, and dried in critical point dryer (Emitech; K850). After sputter-coating with gold by using an ion coater (Eiko Engineer; IB-2), they were examined with a scanning electron microscope (SEM) (Jeol; JSM5600LV) which operated at $10 \mathrm{kV}$. For transmission electron microscopy, $3 \mathrm{~mm}$ root tip segments were fixed overnight in $2.5 \%$ glutaraldehyde in a $0.1 \mathrm{M}$ sodium phosphate buffer ( $\mathrm{pH}$ 7.2). They were postfixed for $2 \mathrm{~h}$ in $2 \%$ osmium tetroxide in water. The roots were embedded in a Spurr's resin and polymerized for $7 \mathrm{~h}$ at $80^{\circ} \mathrm{C}$. Next, $60 \mathrm{~nm}$ cross-sliced sections, probably located in the middle part between the root tip and the quiescent center in the root cap, were made on an ultramicrotome (Leica; UCT) and stained with $5 \%(\mathrm{w} / \mathrm{v})$ uranyl acetate and $2 \%(\mathrm{w} / \mathrm{v})$ lead citrate. After fixing, the specimens were examined with a transmission electron microscope (TEM) (Jeol; JEM1220) which operated at $80 \mathrm{kV}$.

\section{Statistical analysis}

All statistical analyses were performed as analysis of variance (ANOVA) and means were compared using Duncan's multiple range test (DMRT) at $p \leq 0.05$.

\section{Results and discussion}

Responses of antioxidative enzyme activities to Nostoc sp. extract were determined as an indicator of oxidative stress. Antioxidative enzymes are involved in the detoxification and balance of reactive oxygen species (ROS) when oxidative stress occurs (Mittler 2002). After $24 \mathrm{~h}$ of exposure, CAT, APX, GR, and PODs activities significantly increased with increasing extract concentration (Figure 1a-d). CAT and PODs are enzymes which convert $\mathrm{H}_{2} \mathrm{O}_{2}$ to water and protect the cells from the damaging effects of $\mathrm{H}_{2} \mathrm{O}_{2}$ - a precursor of hydroxyl radical $\left(\mathrm{HO}^{*}\right)$ which is a high oxidative power molecule. APX and GR are enzymes which are involved in the ascorbate-glutathione cycle. CAT and the ascorbate-
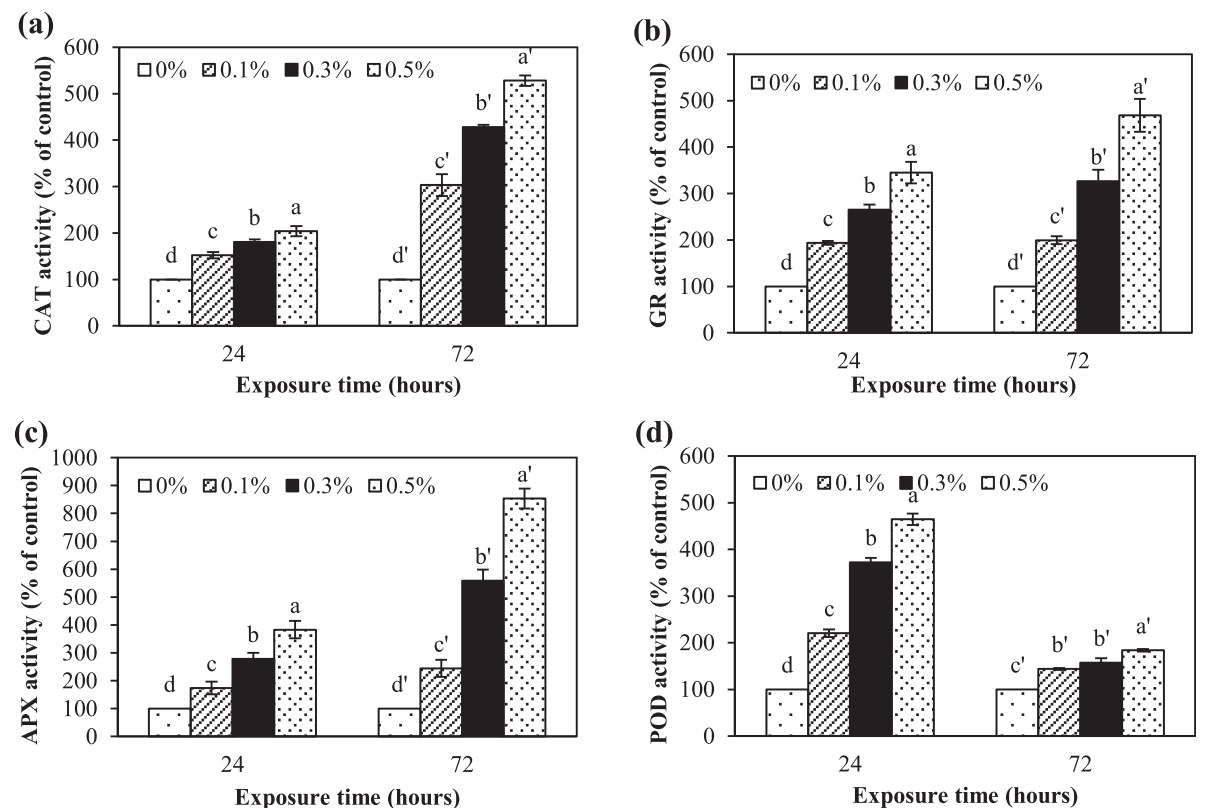

Figure 1 Antioxidative enzyme activities in M. pigra roots after exposure to the extract at different concentrations for 24 and $72 \mathrm{~h}$. CAT (a), GR (b), APX (c), and PODs (d) Data are mean values of three replications and SD are indicated by vertical bars. The different letters above the column indicate significant differences $(p \leq 0.05)$ by DMRT. 
glutathione cycle are important in $\mathrm{H}_{2} \mathrm{O}_{2}$ scavenging. CAT has a high reaction rate, but a low affinity for $\mathrm{H}_{2} \mathrm{O}_{2}$, so its function is only removing the bulk of $\mathrm{H}_{2} \mathrm{O}_{2}$. APX has a higher affinity for $\mathrm{H}_{2} \mathrm{O}_{2}$ so it can scavenge small amounts of $\mathrm{H}_{2} \mathrm{O}_{2}$ in more specific locations (Dat et al. 2000). For PODs activity that highly increased at $24 \mathrm{~h}$ after treatment but drastically reduced at $72 \mathrm{~h}$ indicating a sensitivity of PODs at the initial stress condition $(24 \mathrm{~h})$ but not after prolonged stress $(72 \mathrm{~h})$. This was similar to the response of guaiacol peroxidases to cadmium that was decreased with high concentration but not with low concentration (Cho and Seo 2005). Other enzymes involved in $\mathrm{H}_{2} \mathrm{O}_{2}$ scavenging (APX and CAT) seemed to be principal than PODs at $72 \mathrm{~h}$ after treatment. Several studies have been reported that there is an increase in antioxidative enzyme activities upon allelochemical stress; for example, Pflugmacher et al. (2006) reported that enhanced activities of SOD, CAT, PODs, and GR in alfalfa (Medicago sativa L.) in response to oxidative stress caused by the exposure to cyanobacterial metabolites. Essential oils from redstem wormwood (Artemisia scoparia Waldst \& Kit.) induced oxidative stress in wheat (Triticum aestivum L.) roots and elevated antioxidative enzyme activities (Kaur et al. 2012). All antioxidative enzyme activities kept increasing within $72 \mathrm{~h}$, except for PODs (Figure 1a-d). These results suggest that Nostoc sp. extract might cause oxidative stress resulting in a significant activation of antioxidative enzyme activities.

Effect of Nostoc sp. extract on ROS (superoxide anion radicals $\left(\mathrm{O}_{2} \bullet^{-}\right)$and $\left.\mathrm{H}_{2} \mathrm{O}_{2}\right)$ production were detected. Dihydroethidium has been widely used to evaluate ROS production, mainly of $\mathrm{O}_{2} \bullet^{-}$. It can freely permeate cell membranes and react with $\mathrm{O}_{2}{ }^{-}$to form a red fluorescent product (Gomes et al. 2005). Our results showed a slightly red fluorescence at 0.3 and $0.5 \%$ of the extract concentrations after exposure for $24 \mathrm{~h}$. After $72 \mathrm{~h}$, roots were stained stronger and produced a brighter fluorescence at a concentration $0.1-0.5 \%$ than in the control (Figure 2). This indicated that the extract induced ROS production (presumably $\mathrm{O}_{2} \bullet^{-}$), but the exact mechanism is not known. There were reports that ROS can be generated as by-products of biotransformation reactions of toxins (Lee and Farrell 2001; Pflugmacher 2004; Lushchak 2012). Superoxide anion radicals can be produced from mitochondria when respiration is suppressed, $\mathrm{NADPH}$ oxidase on plasma membranes, peroxisome, and endoplasmic reticulum and serves as the precursor of other harmful ROS (Sharma et al. 2012).

$\mathrm{H}_{2} \mathrm{O}_{2}$ content in treated roots was not drastically different from the control at 24 and $72 \mathrm{~h}$ after treatment but the trends of the $\mathrm{H}_{2} \mathrm{O}_{2}$ content were increased at both times of exposure (Figure 3). $\mathrm{H}_{2} \mathrm{O}_{2}$ is one of ROS molecule which can be converted from $\mathrm{O}_{2}{ }^{-}$and these two molecules were used to indicate oxidative stress level in many researches (Bai et al. 2009; Lara-nuñez et al. 2006). The results showed that the treated roots induced the higher production of $\mathrm{O}_{2} \bullet^{-}$and $\mathrm{H}_{2} \mathrm{O}_{2}$ than in the control confirming the potential of Nostoc sp. extract in oxidative stress induction. However, ROS also correlated with antioxidative enzyme activities. The results of antioxidative enzyme activities except for PODs showed the increase at 24 and $72 \mathrm{~h}$ indicating the occurrence of oxidative stress. The cells have to induce the antioxidative enzyme activities to balance ROS level resulting in slight difference of $\mathrm{H}_{2} \mathrm{O}_{2}$ content between treatment and control. This was supported by the study of Singh et al. (2007) who found that arsenic induced oxidative stress in mung bean (Phaseolus aureus Roxb.) which was corresponded to the increase of antioxidative enzyme activities, but not to $\mathrm{H}_{2} \mathrm{O}_{2}$ accumulation.

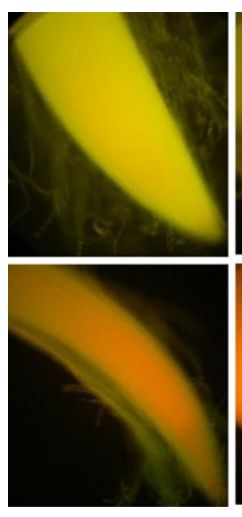

0

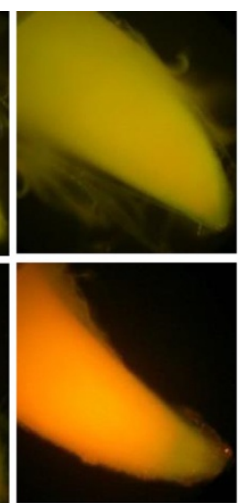

0.1

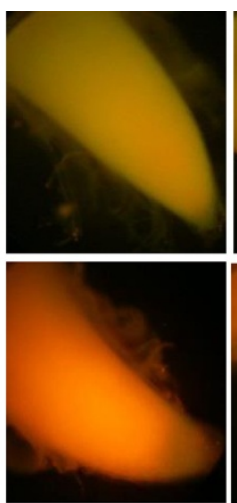

0.3

Extract concentrations (\%)

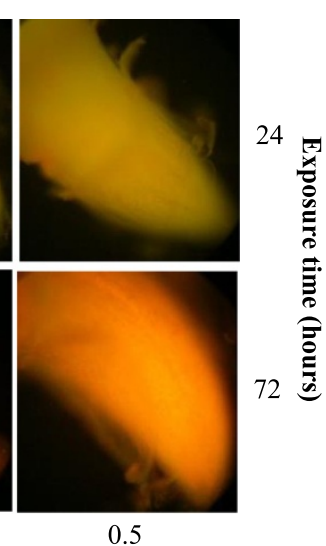

0.5

Figure 2 ROS production in M. pigra roots after exposure to the extract at different concentrations for 24 and 72 h (upper and lower rows). Red fluorescence shows ROS production (presumably $\mathrm{O}_{2}{ }^{-}$). 


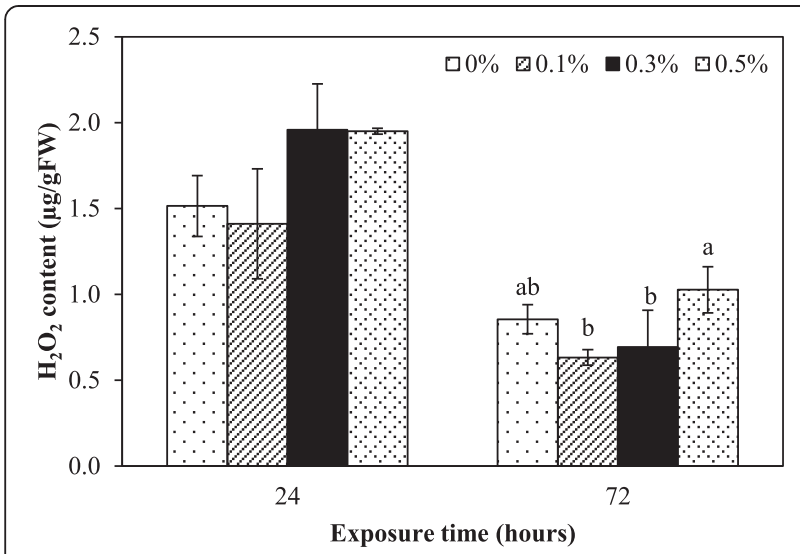

Figure 3 Hydrogen peroxide content in $M$. pigra roots after exposure to the extract at different concentrations for $\mathbf{2 4}$ and $72 \mathrm{~h}$. Data are mean values of three replications and SD are indicated by vertical bars. The different letters above the column indicate significant differences $(p \leq 0.05)$ by DMRT.

Cell death occurred after roots were exposed to the extract for 24 and $72 \mathrm{~h}$. This was indicated by relative Evans blue uptake (Figure 4). At $24 \mathrm{~h}$, the uptake of Evans blue was not different from the control with roots exposed to the extract at a concentration of $0.1 \%$, but the uptake gradually increased at 0.3 to $0.5 \%$. Evans blue uptake of treatment with 0.3 and $0.5 \%$ dramatically increased about 7 and 11 times more than that of the control at $72 \mathrm{~h}$, respectively (Figure 4). Evans blue is a non-permeating stain which can pass through a damaged plasma membrane of a dead cell and is generally used to indicate the degradation of the plasma membrane and cell death (Peterson et al. 2008). Our results indicated that the extract caused the loss of membrane integrity and strongly induced cell death at $72 \mathrm{~h}$. This

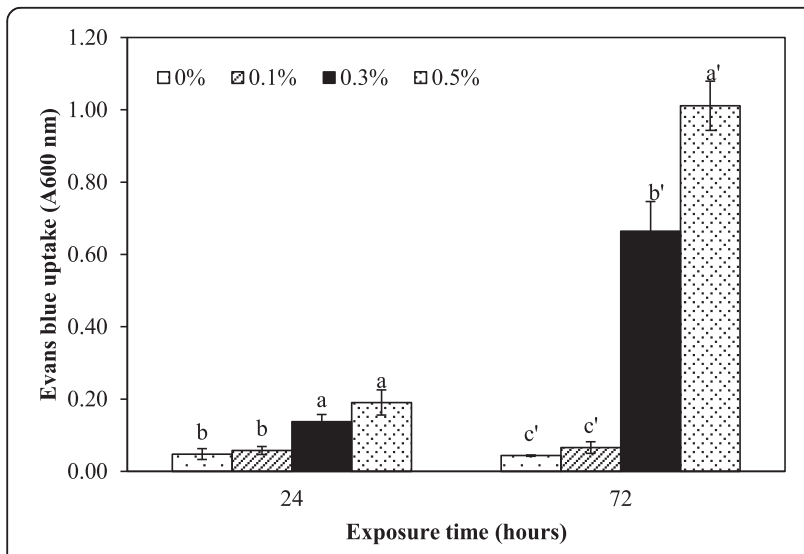

Figure 4 Uptake of Evans blue in M. pigra root tips after exposure to the extract at different concentrations for $\mathbf{2 4}$ and $72 \mathrm{~h}$. Data are mean values of three replications and SD are indicated by vertical bars. The different letters above the column indicate significant differences $(p \leq 0.05)$ by DMRT. result was supported by Volk and Mundt (2007) who studied the cytotoxicity of exometabolites from Nostoc insulare culture, resulting in human amniotic epithelial cell death. There are some reports about the effect of cyanobacterial toxins on plant cell death. For example, microcystin-RR from Microcystis aeruginosa decreased cell viability of tobacco (Nicotiana tabacum L. cv. BY-2) cell line after treatment for $144 \mathrm{~h}$ (Yin et al. 2005). Sanevas et al. (2007) reported that crude extract from Hapalosiphon sp. caused cell death in onion (Allium cepa L. cv. Raputa II) and wheat (Triticum aestivum L. cv. Norin $61)$ roots. In general an increase in the number of cell death when the concentration and time were increased correlated with activation of ROS production, suggesting ROS caused oxidative stress and cell death despite increased antioxidative enzyme activities. This may be due to an imbalance that the production of ROS is over antioxidant defenses.

Effect of Nostoc sp. extract on lipid peroxidation was investigated by determining malondialdehyde (MDA) content, which is a by-product of the peroxidation of membrane lipids. MDA content at $24 \mathrm{~h}$ significantly increased with higher concentrations. There was no significant difference between MDA content at various concentrations and the control at $72 \mathrm{~h}$ after exposure (Figure 5). The results showed that elevated lipid peroxidation, indicator of oxidative damage, is an important feature of the toxicity of the extract to $M$. pigra roots. These results agree with other cyanobacterial extract that have involved MDA content and lipid peroxidation. It has been reported that microcystins from cyanobacterial bloom material induced oxidative damage, such as lipid peroxidation, in alfalfa (Medicago sativa L.) seedlings (Pflugmacher et al. 2006). Microcystin-LR can

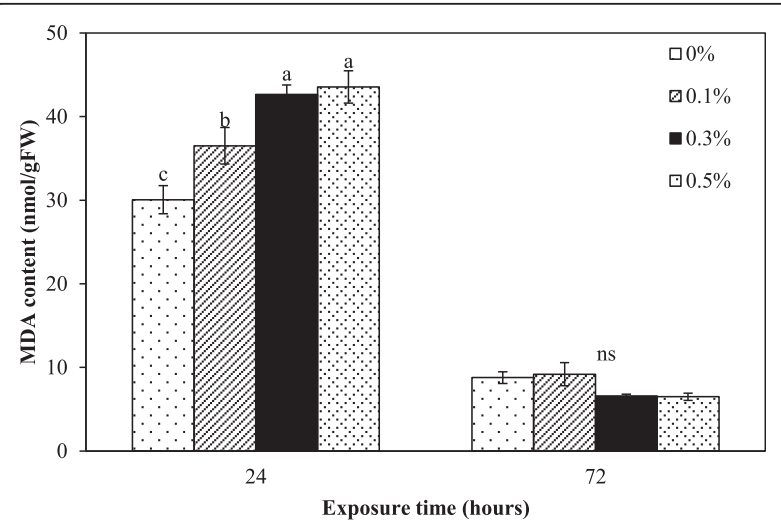

Figure 5 MDA content of $M$. pigra roots exposed to different concentrations of the extract for 24 and $\mathbf{7 2} \mathrm{h}$. Data are mean values of three replications and SD are indicated by vertical bars. The different letters above the column indicate significant differences $(p \leq 0.05)$ at each time by DMRT. ns $=$ no significant difference. 


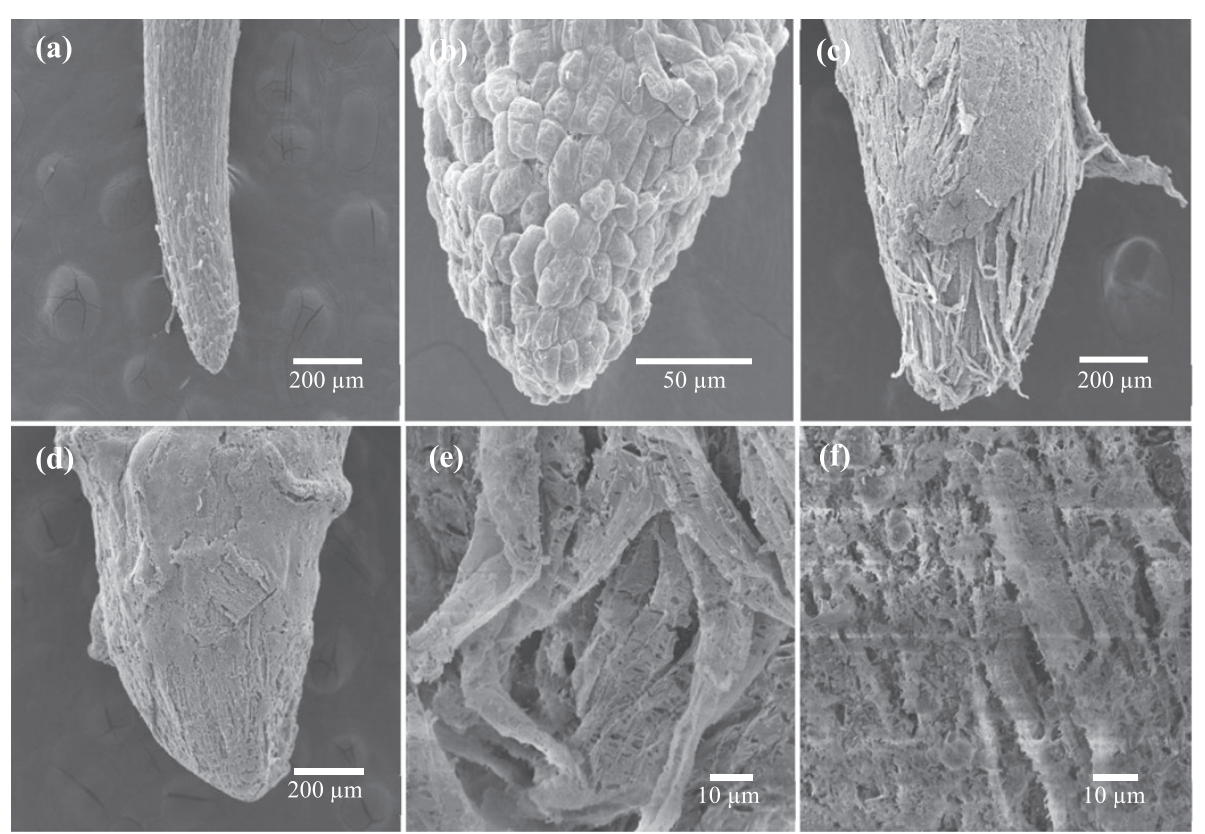

Figure 6 SEM micrographs of $M$. pigra root tips treated with an extract from Nostoc sp. for 72 h. (a) control (magnification $=80 \mathrm{x})(\mathbf{b})$ healthy root cap from the control (500x) (c, $\mathbf{d})$ roots grown in $0.5 \%$ of the extract $(80 \mathrm{x})$ and $(\mathbf{e}, \mathbf{f})$ root tip cell damage in the treatment with $0.5 \%$ of the extract $(1,000 x)$.
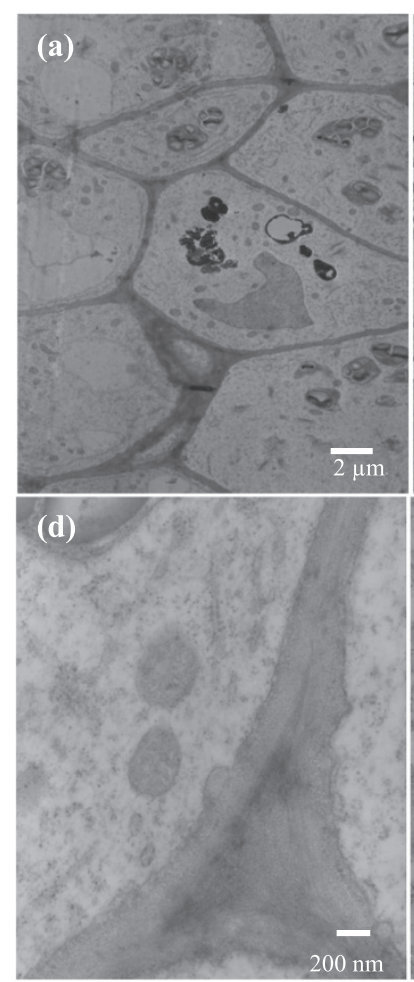

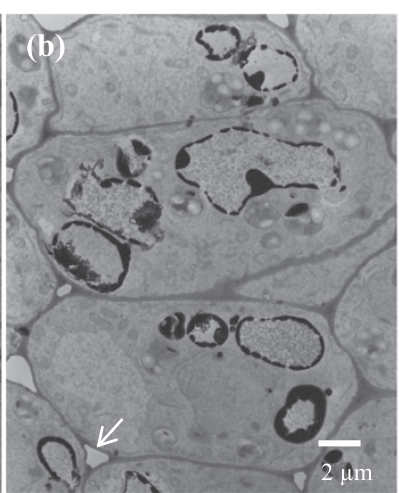

(e)

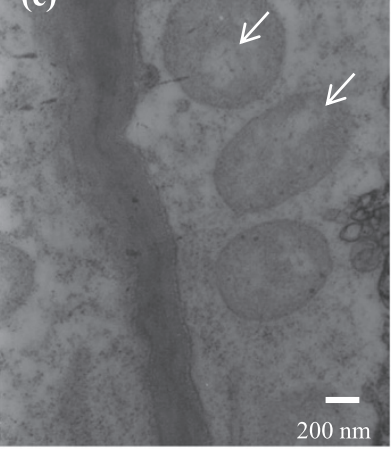

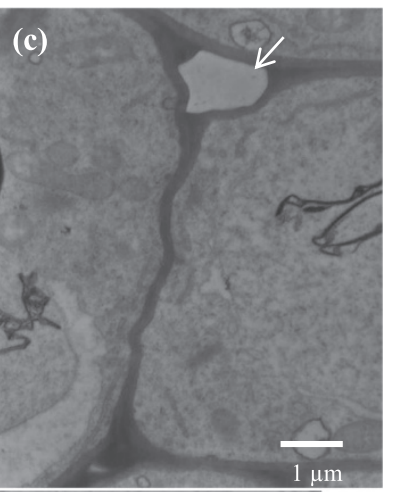
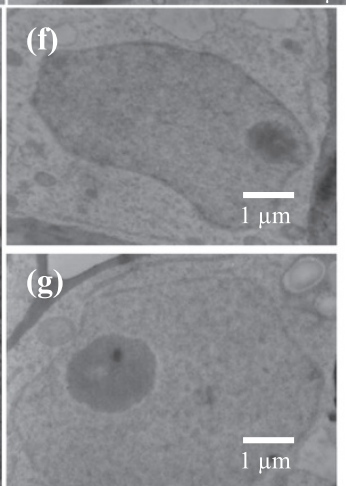

Figure 7 TEM micrographs of $\boldsymbol{M}$. pigra root tips treated with an extract from Nostoc sp. for $\mathbf{7 2}$ h. (a) control (magnification $=2,500 \mathrm{x}$ ) (b) treated root (2,500x) showing some substances stored vacuoles and the dissolution of the middle lamella (white arrow) (c) treated root (8,000x) showing the dissolution of the middle lamella (white arrow) (d) mitochondria of the control (20,000x) (e) swollen mitochondria in treated root (20,000x) showing indistinct cristae (white arrows) (f, $\mathbf{g})$ normal nucleus of control and treated root $(5,000 x)$. 
increase MDA content in Vallisneria natans (Lour.) Hara (Jiang et al. 2011). Koodkaew et al. (2012a, b) showed that ambiguine $\mathrm{D}$ isonitrile and hapalocyclamide from the cyanobacterium, Hapalosiphon sp., increased MDA content and caused cell death in lettuce (Lactuca sativa L.) seedlings. Normally, MDA levels can be correlated with ROS levels (Yin et al. 2005; Koodkaew et al. 2012a, b). The extract might induce ROS production in the cells and cause oxidative damage such as peroxidation of lipids, causing initial cell death at $24 \mathrm{~h}$. The lack of a difference of MDA content at $72 \mathrm{~h}$ might be the result of extremely damaged cell membrane leading to metabolite leakage under longer of exposure because it correlated with the severe cell death at $72 \mathrm{~h}$ after treatment (Figure 4).

Changes of root ultrastructure after Nostoc sp. extract exposure were investigated by using electron microscope. After $72 \mathrm{~h}$ of exposure, SEM micrographs showed completely changed root tip cells/structures between the control and the treated roots. The control roots were narrower and more elongated than those of the treated roots (Figure 6). The root tip cells and epidermal cells of the control roots were intact while the epidermis peeled off and the root cap destructed in the treated roots (Figure 6a-b, c-d). These ultrastructural changes confirmed that cell damage was caused by the extract. It has been reported that some allelochemicals such as two sesquiterpene-derivatives from Ageratina adenophora (Asteraceae) caused irregular shapes of root tip cells with a greater number of separated cells and the collapse of the root cap cells (Yang et al. 2011). Burgos et al. (2004) reported that allelochemical from rye (Secale cereal L.) reduced the differentiation of root cap cells of cucumber (Cucumis sativus L.) seedlings. The extract had severe effects on root cap and epidermal cells. It might be caused by the susceptibility of root cap and epidermal cells to the environment. The extract could easily penetrate the cell walls and enter the cells.

Disaggregation and destruction of root tip cells (Figure 6e-f) indicate that the extract affected the cell structure by disintegrating the middle lamella as shown in a TEM micrograph (Figure 7b-c). Beers (1997) reported that the dissolution of middle lamella and cell wall occur when plant cells undergo cell death. Roots response to environmental stress by the increase of lignin production resulting cell wall lignification and stunted roots (Siegel 1993). Disaggregation of root tip cells might be caused by the continued expansion of the stele and a rigidification of the roots. TEM micrographs also showed swollen mitochondria and indistinct cristae in treated roots (Figure 7e). Mitochondria are one of the major sources of ROS in roots (Mano 2002; Gill and Tuteja 2010) which can cause oxidative damage in cells. Jones (2000) reported that swollen organelles and broken plasma membranes are stages of cell death when metabolic homeostasis fails and mitochondria contribute to apoptotic cell death. Continuous damage of mitochondria becomes irreversible and ensures cell death (Van Loo et al. 2002). Diaz-Tielas et al. (2012) showed that alteration of mitochondrial membranes, swollen mitochondria, and the induction of irreversible cell death were due to the phytotoxicities of chalcone on Arabidopsis thaliana (L.) Heynh. seedlings.

\section{Conclusions}

Based on our results, we conclude that a Nostoc sp. extract enhanced oxidative stress by ROS production resulting in lipid peroxidation of cell membranes and cell death despite the activation of antioxidative enzymes. This was confirmed by destruction of root tip cells and aberrant mitochondria. These results are consistent with our previous study that the extract inhibited root growth of $M$. pigra by inducing oxidative stress and cell death. To clarify the mechanism of action of Nostoc sp. extract provides benefit information for application to use as natural herbicide and control M. pigra - invasive weed in some parts of the world. The extract might be developed to use as bioherbicide for weed control. The effects of this extract on other weed species, field experiment, and purification of bioactive compounds need to be investigated.

\section{Abbreviations \\ APX: Ascorbic acid peroxidase; CAT: Catalase; DHE: Dihydroethidium; GR: Glutathione reductase; $\mathrm{H}_{2} \mathrm{O}_{2}$ : Hydrogen peroxide; $\mathrm{HO}$ : Hydroxyl radical; MDA: Malondialdehyde; NADPH: Nicotinamide adenine dinucleotide phosphate; $\mathrm{O}_{2}{ }^{-}$: Superoxide anion radical; PODs: Peroxidases; ROS: Reactive oxygen species; SEM: Scanning electron microscope; TEM: Transmission electron microscope.}

\section{Competing interests}

The authors declare that they have no competing interests.

\section{Authors' contributions}

SSRP and SNT are responsible for cyanobacteria culture. SSS and SNT supplied all laboratory and chemical substances used in this study. SSRP, SNT, and SSS designed the experiment. SSRP determined, analysed the data, and also drafted the manuscript. All authors read and approved the final manuscript.

\section{Acknowledgements}

We are thankful to the Thai Science Scholar Project, Bilateral Research Cooperation (BRC) from Faculty of Sciences, and Kasetsart University Research and Development Institute (KURDI) for financial support. We also thank Scientific Equipment and Research Division, Kasetsart University for using their electron microscope.

Received: 20 June 2014 Accepted: 15 December 2014 Published online: 22 February 2015

\section{References}

Aebi H (1983) Catalase. In: Bergmeyer HU (ed) Methods in enzymatic analysis, vol 3. Academic Press, New York, pp 276-286

Bai R, Ma F, Liang D, Zhao X (2009) Phthalic acid induces oxidative stress and alters the activity of some antioxidant enzymes in roots of Malus prunifolia. J Chem Ecol 35:488-494 
Beers EP (1997) Programmed cell death during plant growth and development. Cell Death Differ 4:649-661

Berry JP, Gantar M, Perez MH, Berry G, Noriega FG (2008) Cyanobacterial toxins as allelochemicals with potential applications as algaecides, herbicides and insecticides. Mar Drugs 6:117-146

Blom JF, Brutsch T, Barbaras D, Bethuel Y, Locher HH, Hubschwerlen C, Gademann K (2006) Potent algicides based on the cyanobacterial alkaloid nostocarboline. Org Lett 8(4):737-740

Burgos NR, Talbert RE, Kim KS, Kuk YI (2004) Growth inhibition and root ultrastructure of cucumber seedlings exposed to allelochemicals from rye (Secale cerea). J Chem Ecol 30(3):671-689

Cho U, Seo N (2005) Oxidative stress in Arabidopsis thaliana exposed to cadmium is due to hydrogen peroxide accumulation. Plant Sci 168:113-120

Dat J, Vandenabeele S, Vranová E, Montagu MV, Inzé D, Breusegem FV (2000) Daul action of the active oxygen species during plant stress responses. Cell Mol Life Sci 57:779-795

Díaz-Tielas C, Graña E, Sotelo T, Reigosa MJ, Sánchez-Moreiras AM (2012) The natural compound trans-chalcone induces programmed cell death in Arabidopsis thaliana roots. Plant Cell Environ 35:1500-1517

Duke SO, Rimando AM, Schrader KK, Aliotta G, Oliva A, Romagni JG (2002) Chemicals from nature for weed management. Weed Sci 50:138-151

Etchegaray A, Rabello E, Dieckmann R, Moon DH, Fiore MF, Döhren H, Tsai SM, Neilan BA (2004) Algicide production by the filamentous cyanobacterium Fischerella sp. CENA 19. J Appl Phycol 16:237-243

Gill SS, Tuteja N (2010) Reactive oxygen species and antioxidant machinery in abiotic stress tolerance in crop plants. Plant Physiol Biochem 48:909-930

Gomes A, Fernandes E, Lima JLFC (2005) Fluorescence probes used for detection of reactive oxygen species. J Biochem Biophys Methods 65:45-80

Gutteridge JMC (1995) Lipid peroxidation and antioxidants as biomarkers of tissue damage. Clin Chem 41(12):1819-1828

Halliwell B, Chirico S (1993) Lipid peroxidation: its mechanism, measurement, and significance. Am J Clin Nutr 57:715-725

Halliwell B, Foyer CH (1978) Properties and physiological function of a glutathione reductase purified from spinach leaves by affinity chromatography. Planta 139:9-17

Hirata K, Yoshitomi S, Dwi S, Iwabe O, Mahakhant A, Plochai J, Miyamoto K (2003) Bioactivities of Nostocine a produced by a freshwater cyanobacterium Nostoc spongiaeforme TISTR 8169. J Biosci Bioeng 95(5):512-517

Jiang W, Liu D (2010) Pb-induced cellular defense system in the root meristematic cells of Allium sativum L. BMC Plant Biol 10:40

Jiang J, Gu X, Song R, Wang X, Yang L (2011) Microcystin-LR induced oxidative stress and ultrastructural alterations in mesophyll cells of submerged macrophyte Vallisneria natans (Lour.) Hara. J Hazard Mater 190:188-196

Jones A (2000) Does the plant mitochondrion integrate cellular stress and regulate programmed cell death? Trends Plant Sci 5(5):225-230

Junglee S, Urban L, Sallanon H, Lopez-Lauri F (2014) Optimized assay for hydrogen peroxide determination in plant tissue using potassium iodide. Am J Anal Chem 5:730-736

Kaur S, Singh HP, Batish DR, Kohli RK (2012) Artemisia scoparia essential oil inhibited root growth involves reactive oxygen species (ROS)-mediated disruption of oxidative metabolism: in vivo ROS detection and alterations in antioxidant enzymes. Biochem Syst Ecol 44:390-399

Kobayashi A, Kajiyama S (1998) Secondary metabolites of cyanobacteria Nostoc sp. Chin J Oceanol Limnol 16:109-117

Koodkaew I, Sunohara Y, Matsuyama S, Matsumoto H (2012a) Isolation of ambiguine $\mathrm{D}$ isonitrile from Hapalosiphon sp. and characterization of its phytotoxic activity. Plant Growth Regul 68:141-150

Koodkaew I, Sunohara Y, Matsuyama S, Matsumoto H (2012b) Phytotoxic action mechanism of hapalocyclamide in lettuce seedlings. Plant Physiol Biochem 58:23-28

Kreitlow S, Mundt S, Lindequist U (1999) Cyanobacteria-a potential source of new biologically active substances. J Biotechnol 70(1-3):61-63

Kulik MM (1995) The potential for using cyanobacteria (blue-green algae) and algae in the biological control of plant pathogenic bacteria and fungi. Eur Plant Pathol 101(6):585-599

Lara-Nuñez A, Romero-Romero T, Ventura UL, Blancas V, Anaya AL, Cruz-Ortega R (2006) Allelochemical stress causes inhibition of growth and oxidative damage in Lycopersicon esculentum Mill. Plant Cell Environ 29:2009-2016

Lee AU, Farrell GC (2001) Mechanism of azathioprine-induced injury to hepatocytes: roles of glutathione depletion and mitochondrial injury. J Hepatol 35:756-764
Leflaive J, Ten-Hage L (2007) Algal and cyanobacterial secondary metabolites in freshwaters: a comparison of allelopathic compounds and toxins. Freshwater Biol 52:199-214

Lushchak VI (2012) Glutathione homeostasis and functions: potential targets for medical interventions. J Amino Acids 2012:1-26

Mano J (2002) Early events in environmental stresses in plants-induction mechanisms of oxidative stress. In: Inzé D, Montagu MV (eds) Oxidative stress in plant. Taylor \& Francis, London

Mittler R (2002) Oxidative stress, antioxidant and stress tolerance. Plant Sc $7(9): 405-410$

Nakano Y, Asada K (1987) Purification of ascorbate peroxidase in spinach chloroplasts; its inactivation in ascorbate-depleted medium and reactivation by monodehydroascorbate radical. Plant Cell Physiol 28:131-140

Peterson RL, Peterson CA, Melville LH (2008) Technique plant anatomy through creative laboratory exercises. National Research council, Canada

Pflugmacher S (2004) Promotion of oxidative stress in the aquatic macrophyte Ceratophyllum demersum during biotransformation of the cyanobacterial toxin microcystin-LR. Aquat Toxicol 70:169-178

Pflugmacher S, Jung K, Lundvall L, Neumann S, Peuthert A (2006) Effects of cyanobacterial toxins and cyanobacterial cell-free crude extract on germination of alfalfa (Medicago sativa) and induction of oxidative stress. Environ Toxicol Chem 25(9):2381-2387

Putter J (1974) Peroxidases. In: Bergmeyer HU (ed) Methods of enzymatic analysis, vol 2. Academic Press, New York, pp 685-690

Rippka R, Deruelles J, Waterbury JB, Herdman M, Stanier RY (1979) Genetic assignments, strain histories and properties of pure cultures of cyanobacteria. J Gen Microbiol 111:1-61

Sanevas N, Sunohara Y, Matsumoto H (2007) Characterization of reactive oxygen species-involved oxidative damage in Hapalosiphon species crude extract-treated wheat and onion roots. Weed Biol Manag 7:172-177

Sharma P, Jha AB, Dubey RS, Pessarakli M (2012) Reactive oxygen species, oxidative damage, and antioxidative defense mechanism in plants under stressful conditions. J Bot 2012. doi:10.1155/2012/217037

Siegel BZ (1993) Plant peroxidases-an organismic perspective. Plant Growth Regul 12:303-312

Singh HP, Batish DR, Kohli RK, Arora K (2007) Arsenic-induced root growth inhibition in mung bean (Phaseolus aureus Roxb.) is due to oxidative stress resulting from enhanced lipid peroxidation. Plant Growth Regul 53:65-73

Sukkhaeng S, Sanevas N, Suwanwong S (2014) Inhibition of seedling growth in giant mimosa and reduction of mitotic activity in onion root tips caused by cyanobacterial extract. Chiang Mai J Sci 41(5.1):1150-1156

Sunohara Y, Matsumoto H (2008) Quinclorac-induced cell death is accompanied by generation of reactive oxygen species in maize root tissue. Phytochemistry 69:2312-2319

Van Loo G, Saelens X, Van Gurp M, Mac Farlane M, Martin SJ, Vandenabeele P (2002) The role of mitochondrial factors in apoptosis: a Russian roulette with more than one bullet. Cell Death Differ 9:1031-1042

Velikova V, Yordanov I, Edreva A (2000) Oxidative stress and some antioxidant systems in acid rain-treated bean plants protective role of exogenous polyamines. Plant Sci 151:59-66

Volk R, Mundt S (2007) Cytotoxic and non-cytotoxic exometabolites of the cyanobacterium Nostoc insulare. J Appl Phycol 19:55-62

Yamamoto Y, Kobayashi Y, Matsumoto H (2001) Lipid peroxidation is an early symptom triggered by aluminum, but not the primary cause of elongation inhibition in pea roots. Plant Physiol 125:199-208

Yang G, Wan F, Guo J, Liu W (2011) Cellular and ultrastructural changes in the seedling roots of upland rice (Oryza sativa) under the stress of two allelochemicals from Ageratina adenophora. Weed Biol Manag 11:152-159

Yin L, Huang J, Huang W, Li D, Wang G, Liu Y (2005) Microcystin-RR-induced accumulation of reactive oxygen species and alteration of antioxidant systems in tobacco BY-2 cells. Toxicon 46:507-512 